HELMINTHOLOGIA, 52, 3: 195 - 204, 2015

\title{
Intestinal parasitic fauna and zoonotic potentials of commonly consumed wildlife
}

\author{
I. C. OKOYE, K. U. OZIOKO, N. R. OBIEZUE, B. C. IKELE
}

Parasitology and Biomedical Diseases Research Unit; Department of Zoology and Environmental Biology, University of Nigeria, Nsukka, E-mail: ikem.okoye@unn.edu.ng

\section{Article info}

Received December 30, 2014 Accepted April 28, 2015

\begin{abstract}
Summary
A study was carried out in Nsukka cultural zone, Nigeria, with the aim of determining the prevalence, intensity and abundance of intestinal endoparasitic fauna of commonly consumed wildlife or bushmeat. From the 143 wild animals sampled, 141 (98.6\%) were found at least infected with one intestinal parasite. Ascaris lumbricoides was the overall most prevalent (48.8\%). Dicrocoelium hospes differed significantly in age-related prevalence of infection. Significant sex-related difference in infection $(P<0.05)$ was recorded for Strongyloides papillosus, A. lumbricoides, Oesophagostomum columbianum and Moniliformis moniliformis while Taenia saginata and Entamoeba histolytica showed significant seasonal differences in intensity of infection. The results suggest that bush-meats were hosts of various parasites of medical and veterinary importance. There is need for health inspection of bush-meat for trade and consumption.
\end{abstract}

Keywords: wildlife; zoonosis; intestinal parasites; prevalence; bush-meat

\section{Introduction}

Meat of wild animals widely referred to as bush-meat has the advantage of having less saturated fat, which makes it healthier than other fatty meats, low calories when compared with beef and pork, high level of Eicosapentaenoic acid, an essential omega-3 fatty acid that has several health benefits and because they grow in natural environments, they are rich in vitamins and minerals. Thus, bush-meat is a good source of organic meat (Oboye, 2013). However, despite these benefits, great caution must be taken when handling or consuming bush-meat. The animals are usually caught in traps, killed by hunters and in some cases, found dead in the bush and sold into the market straight away, without any meat inspection procedures carried out on the carcass by a professional to examine and guarantee that their flesh and organs are free of diseases. These meat can be portable sources of food-borne contaminants and pathogens (Oboye, 2013).

The majority of infectious diseases that have emerged worldwide are considered to be zoonotic, and of these emerging diseases, $70 \%$ are believed to have originated among wildlife (WHO, 2012).
The percentage of wild animals that are carriers for zoonotic diseases is increasing, resulting in a growing concern for human safety and control. Commonly consumed wild life serve as food for man and as reservoir hosts of parasites that cause diseases to man. Informal and unregulated bush-meat supply chain offers a realm of opportunities for human exposure to wildlife that potentially harbour a diversity of zoonotic pathogens. Therefore, possibility of transmission of parasites of the bush-meat to human cannot be overlooked.

Quantitative information regarding bush-meat, as hosts of zoonotic pathogens or their vectors is lacking and needful since information about the distribution of these parasites and their hosts speak to the potential of transmission of human infectious diseases and comparisons of parasite burdens between groups of hosts which is central to understanding host-parasite interactions and transmission patterns.

The present research seeks to fill all these information gaps and in addition, to provide baseline data to assist health planners in developing appropriate evidence-based strategies to prevent and control the spread of zoonotic infections. 


\section{Material and Methods}

\section{Study sites}

The study was carried out between September 2013 and August 2014 in Nsukka cultural zone, Nigeria, located in northern part of Enugu State on longitude 708' and 7020' East and latitude 646' and $6^{\circ} 49^{\prime}$ North. It is made up of seven densely populated Local Council Areas and an estimated population of 1,377,001. The mean temperatures is hottest in the month of February, at about $87.168 \mathrm{~F}(30.648 \mathrm{C})$, while the lowest temperatures occur in the month of November, reaching 60.548F (15.868C). (Okoye et al., 2011) Also, it has tropical relative humidity, with a mean annual range between 40 and $80 \%$. The daily and annual peaks occur very early in the morning and during the rainy season, respectively. Collection of faecal samples, sexing and ageing of the animals were carried out at the point of collection from the hunters.

Animal samples collections

A total of 143 commonly consummed wild life were sampled. These included 33 birds (17 bush fowls (Francolinus bicalcarutus), 16 guinea fowls (Numida meleagris); 77 mammals (16 striped land squirrels (Xenus erythropus), 16 Grasscutters (Thryonomys swin- derianus), 15 wild rabbits (Oryctolagus cuniculus), 15 Maxwell's Duikers (Philantomba maxwellii) and 15 Grimm's duikers (Sylvicapra grimmia) and 33 reptiles (17 African savannah monitor lizards (Varanus exanthematicus), 16 Ornate monitor lizards (Varanus ornatus). The animals were obtained directly from the kills of 60 hunters. Host terminology follows Dekeyser and Derivot (1966, 1967) for birds; Walker (1999) for mammals and Molnar and Pianka (2004), Koch (2010) for Varanoid lizards.

\section{Laboratory analysis}

Faeces were taken from the rectum of freshly killed carcases or from live animals with the aid of long forceps. The faecal samples were examined within 12 hours after collection. Faeces collected were broken up with applicator sticks to check for adult parasites. Adult parasites recovered were preserved in $10 \%$ formalin. The samples were examined by direct smear to establish the presence of intestinal parasites. A combination of modified stoll's dilution technique and faecal sedimentation technique (Soulsby 1982) were used to examine the faecal samples for ova. Egg counts per gram of faeces (EPG) and oocyst counts per gram of faeces (OPG) were evaluated quantitatively using Modified Stoll's Dilution Technique' as described by Soulsby (1982). The parasites were identified at

Table 1. Overall prevalence and mean intensity of intestinal parasites in Nigeria

\begin{tabular}{|c|c|c|}
\hline Intestinal Parasites & $\begin{array}{c}\text { Prevalence (\%) } \\
(95 \% \mathrm{Cl})\end{array}$ & $\begin{array}{l}\text { Mean intensity } \\
\quad(95 \% \mathrm{Cl})\end{array}$ \\
\hline \multicolumn{3}{|l|}{ (a) NEMATODES } \\
\hline Strongyloides papillosus & $21.7(15.61-29.31)$ & $235.48(183.37-306.45)$ \\
\hline Capillaria bursata & $18.2(12.5-25.46)$ & $215.38(161.54-303.85)$ \\
\hline Ascaridia galli & $21.7(15.61-29.31)$ & $345.16(267.74-461.29)$ \\
\hline Trichuris trichiura & $23.1(16.7-30.72)$ & $263.64(209.09-333.33$ \\
\hline Ascaris lumbricoides & $48.8(36.69-53.15)$ & $259.38(217.19-310.94)$ \\
\hline Heligmosomoides polygyrus & $1.4(0.25-5.09)$ & $100.00(0.00-0.00)$ \\
\hline Trichostrongylus retortaeformis & $11.9(7.25-18.44)$ & $288.24(194.12-417.65)$ \\
\hline Enterobius vermicularis & $4.2(1.85-8.97)$ & $183.33(116.67-216.67)$ \\
\hline Ancylostoma sp & $2.1(0.58-6.14)$ & $100.00(0.00-0.00)$ \\
\hline Metastrongylus elongatus & $21.0(14.96-28.61)$ & $196.67(156.67-253.33)$ \\
\hline Globocephalus diducta & $4.9(2.32-9.70)$ & $257.14(128.57-442.86)$ \\
\hline Oesophagostomum columbianum & $7.7(4.03-13.20)$ & $154.55(109.09-200.00)$ \\
\hline \multicolumn{3}{|l|}{ (b) PLATHYHELMINTHES } \\
\hline Taenia saginata & $4.9(2.32-9.7)$ & $185.71(114.29-314.29)$ \\
\hline Hymenolepis nana & $5.6(2.63-10.7)$ & $300.00(175.00-500.00)$ \\
\hline Dicrocoelium hospes & $10.5(6.15-16.69)$ & $146.67(113.33-186.69)$ \\
\hline \multicolumn{3}{|l|}{ (c) ACANTHOCEPHALANS } \\
\hline Moniliformis moniliformis & $12.6(7.94-19.15)$ & $233.33(166.67-322.22)$ \\
\hline \multicolumn{3}{|l|}{ (d) PROTOZOANS } \\
\hline Entamoeba histolytica & $9.8(5.85-15.98)$ & $171.43(121.43-228.59)$ \\
\hline Eimeria tenella & $9.1(5.1-14.95)$ & $500.00(307.69-961.54)$ \\
\hline
\end{tabular}




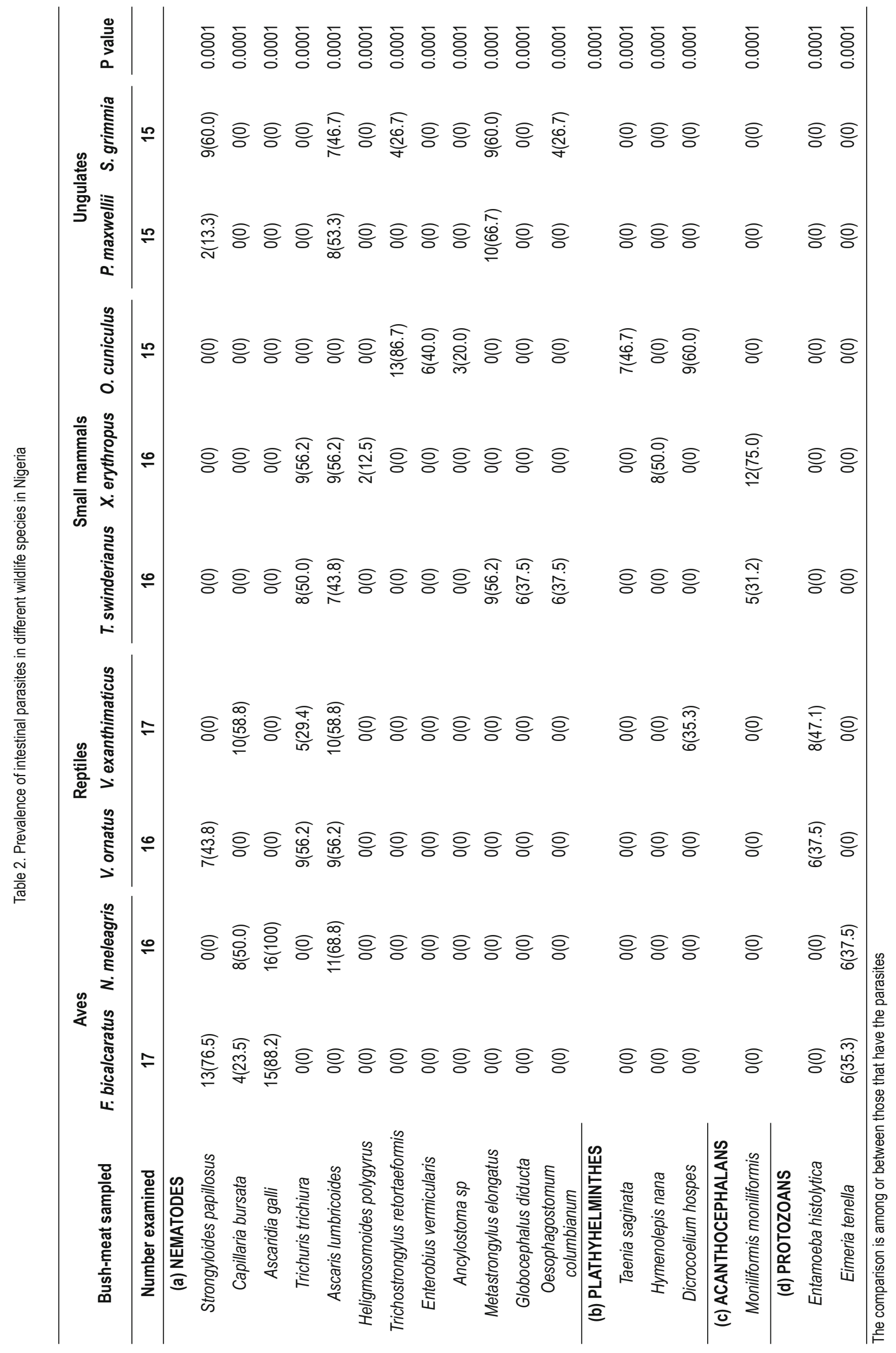




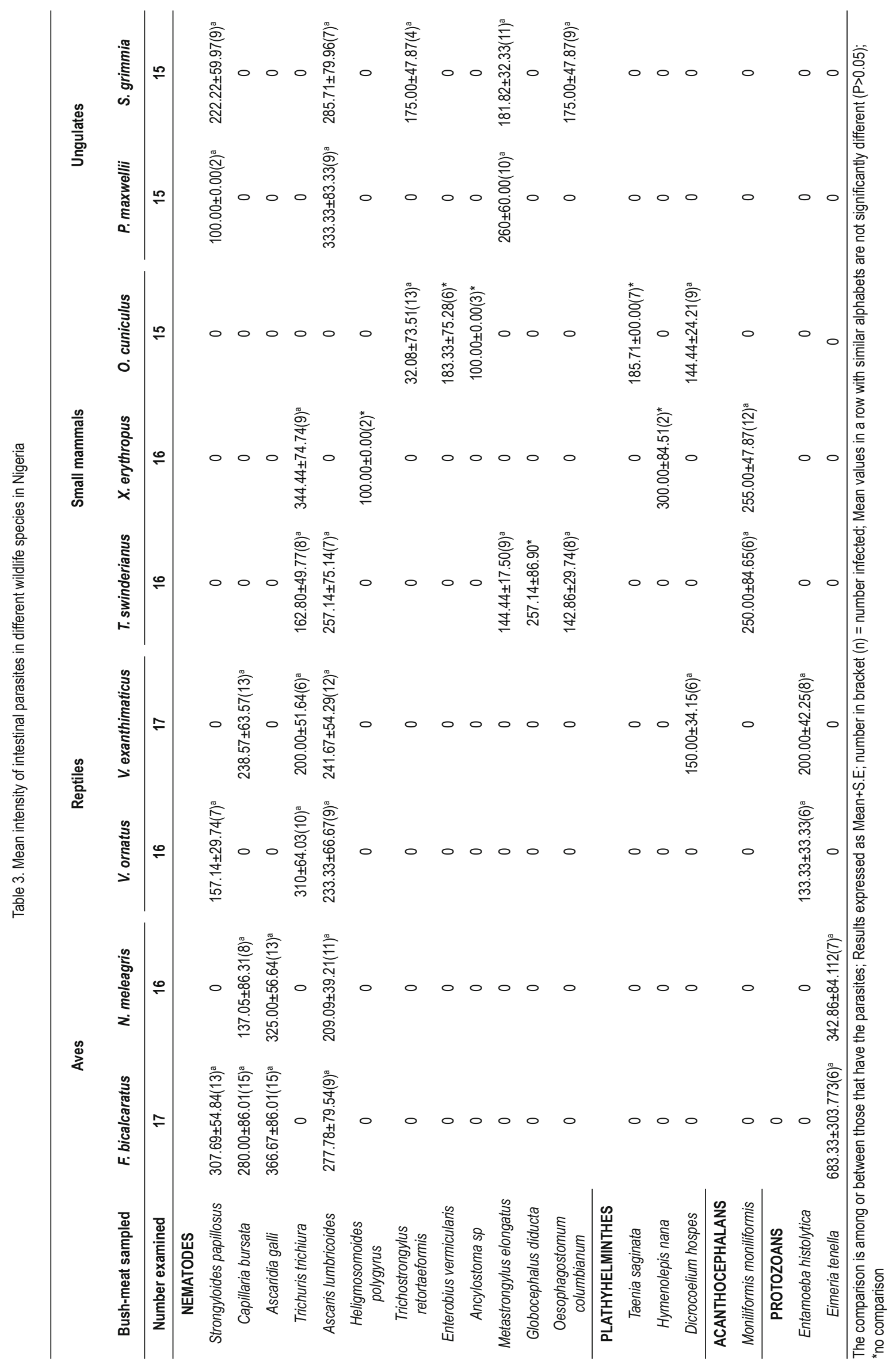


least to genus level based on standard morphological characteristics (Sloss et al., 2004; Lynne and David, 2005) and the representative image of the parasites were captured using motif cam.

\section{Statistical analysis}

The data was keyed into excel and checked for missing data. Overall prevalence and confidence interval were obtained using Quantitative Parasitology (version 3.0). The prevalence of intestinal parasites were determined using Chi square test from the contingency tables while Fisher's exact test was used to calculate significant difference in prevalence for age, sex and season. One way ANOVA was used to determine significant difference in intensity and abundance for animal species. Independent t-test was used to compare intensity and abundance of parasites by age, sex and season. Analysis was done using SPSS (version 20.0) statistical software. Significant difference was set at $P=0.05$ and all tests were performed with a $95 \%$ confidence level.

\section{Results}

Overall prevalence, mean abundance and mean intensity Overall, nineteen genera of intestinal parasites which belong to four phyla; nematode, platyhelminthes, acanthocephalan and protozoa were found infecting commonly consumed bush-meat in the study area (Table 1). Infection with the nematode, A. lumbricoides was the most prevalent $(48.8 \%$ at $36.69-53.15$ mean interval (95\%), mean abundance of 116.08 (89.51 - 148.95). The highest mean intensity was recorded for Eimeria tenella and recovered from birds only $(500.00,95 \%$ confidence interval 307.65 - 961.54). Nematode parasites Heligomosomoides polygyrus had the least prevalence $(1.4 \%)$, least mean intensity $(100.00)$ and least mean abundance (1.40) at $95 \%$ confidence interval of $(0.25$ $-5.09)(0.00-0.00)$ and $(0.00-3.50)$ respectively and recovered from one out of nine different phyla of animals sampled. $D$. hospes was the most prevalent platyhelminthes parasites recorded while $H$. nana was highest in intensity and abundance.

\section{Prevalence of intestinal parasites}

Prevalence of intestinal parasites in different wild animal species collected is presented in (Table 2). In animals infected with $S$. papillosus, the prevalence was highest in F. bicalcarutus (76.5\%) followed by V. ornatus (43.8 \%) and least in P. maxwellii (13.3 \%). In bush-meat infected with Capillaria bursata, the prevalence was highest in $V$ exanthimaticus $(58.8 \%)$ followed by $N$. meleagris $(50 \%)$ and least in F. bicalcarutus (23.5\%). In bush-meat infected with Ascaridia galli, the prevalence was higher in N. meleagris $(100 \%)$ than in F. bicalcarutus. In bush-meat infected with Trichuris trichiura prevalence was highest in $X$. erythropus and $V$. exanthimaticus (56.2\%) and least in (29.4\%). In bush-meat infected with $A$. lumbricoides, prevalence was highest in $N$. meleagris $(68.8 \%)$ and least in $T$. swinderianus (43.8 \%). In bush-meat infected with Trychostongylus retortaeformis, prevalence was higher in 0 . cuniculus sp (86.7\%) than S grimmia. In bush-meat infected with Metastrongylus elongatus, prevalence was highest in P. Maxwellii $(66.7 \%)$ and least in T. swinderianus (56.2\%). In bush-meat infected with Oesophagostomum columbianum, prevalence was higher in T. swinderianus (37.5 \%) than in S. grimmia. In bushmeat infected with $D$. hospes, the prevalence was higher in 0 . cuniculus $(60.0 \%)$ than $V$. exanthimaticus. In bush-meat infected with $M$. moniliformis, the prevalence was higher in $X$. erythropus $(75.0 \%)$ than in $T$. swinderianus. In bush-meat infected with $E$. histolytica, prevalence was higher in V exanthimaticus (47.1\%) than in $V$. orantus. In bush-meat infected with Eimeria sp, prevalence was higher in N. meleagris (37.5\%) than in F. bicalcarutus. The comparison was among or between those that had the parasites and there were significant differences in each of the comparison $(P<0.05)$.

\section{Mean intensity of intestinal parasites}

The intensity of intestinal parasites in different wild animal species collected is presented in (Table 3). F. bicalcarutus had the highest intensity of S. papillosus, highest intensity of Capillaria bursata and highest intensity of $A$. galli when compared with the other animals that had any of these parasites. While $X$. erypthropus had the highest intensity of $T$. trichiura and $M$. moniliformis when compared with the other animals that had any of these parasites and again $P$. maxwellii had the highest intensity of $A$. lumbricoides and Metastrongylus elongatus when compared with the other animals that had any of these parasites. S. grimmia had the highest intensity of Trichostrongylus retortaeformis and 0 . columbianum when compared with the other animals that had any of these parasites. but $V$. exanthimaticus sp had the highest intensity of $D$. hospes and E. histolytica, when compared with the other animals that had any of these parasites. Overall, no significant differences in intensity were observed in comparison between or among the animals that had the same parasites. $(P>0.05)$.

\section{Mean abundance of intestinal parasites}

The mean abundance of $S$. papillosus in wild animals showed that $F$. bicalcarutus had significantly $(P<0.05)$ high mean abundance of $S$. papillosus when compared to other wild animals. (Table 4). The mean abundance of $S$. papillosus in S. grimmia and V. ornatus were not differed significantly $(P>0.05)$. $P$. Maxwellii had the least mean abundance of $S$. papillosus. The mean abundance of $A$. lumbricoides in wild animals did not differ significantly $(P>0.05)$ while mean abundance of C. bursata, A. galli, T. trichiura, TrichostrongyIus retortaeformis, Metastrongylus elongatus, Oesophagostomum columbianum, $M$. moniliformis, E. histolytica and $E$. tenella differed significantly $(P<0.05)$.

Prevalence of intestinal parasites based on season, sex and age The prevalence of infection between season, sex and age among the bush-meat are presented in (Table 5). The effect of season on the prevalence of endoparasites of bush-meat showed that all parasites prevalence in bush-meat were higher in rainy season than in the dry season for all parasites examined except $A$. galli, A. lumbricoides, Heligomosomoides polygyrus, Trichostrongylus retortaeformis, Globocephalus diducta, $O$. columbianum and $M$. moniliformis that were more in dry season but there was no statistical difference between seasons in the prevalence of any of the parasites $(P>0.05)$. The effect of sex on the prevalence of endoparasites of bush-meat showed that apart from A. galli and T. sag- 


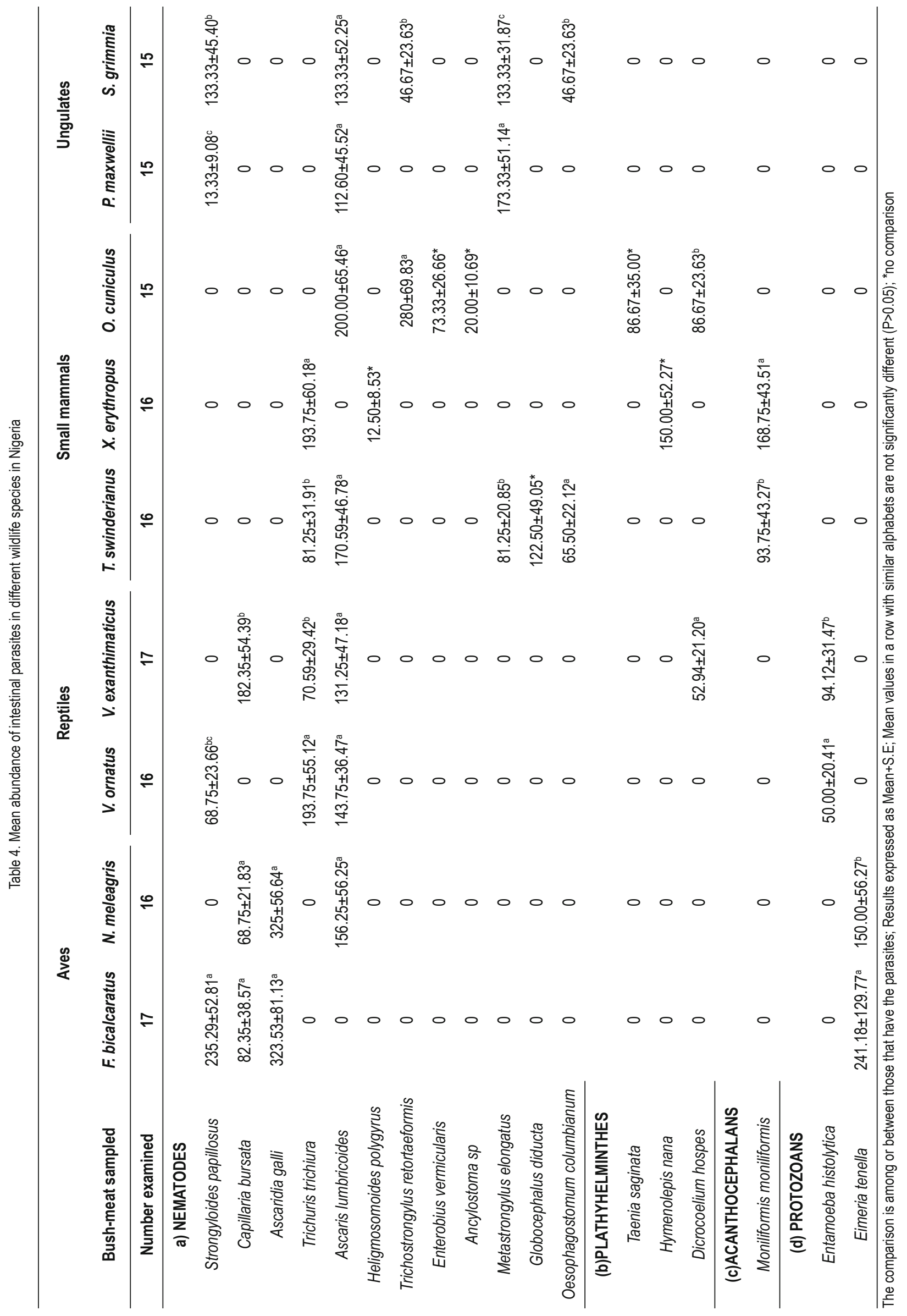


Table 5. Prevalence of Intestinal parasites in wildlife based on season, sex and age in Nigeria

\begin{tabular}{|c|c|c|c|c|c|c|c|c|c|}
\hline \multirow[b]{2}{*}{ Parasites recovered } & \multicolumn{3}{|c|}{ SEASON } & \multicolumn{3}{|c|}{ SEX } & \multicolumn{3}{|c|}{ AGE } \\
\hline & Dry & Rainy & $P$ value & Male & Female & $P$ value & Juvenile & Adult & $P$ value \\
\hline \multicolumn{10}{|l|}{ (a) NEMATODES } \\
\hline Strongyloides papillosus & $13(16.5)$ & 18(28.1) & 0.092 & $14(20.0)$ & $17(23.3)$ & 0.633 & $13(19.1)$ & $18(24.0)$ & 0.479 \\
\hline Capillaria bursata & $11(13.9)$ & $11(17.2)$ & 0.591 & $11(15.7)$ & $11(15.1)$ & 0.915 & $8(11.8)$ & $14(18.7)$ & 0.253 \\
\hline Ascaridia galli & $16(20.3)$ & $15(23.4)$ & 0.644 & $18(25.7)$ & $13(17.8)$ & 0.251 & $14(20.6)$ & $17(22.7)$ & 0.763 \\
\hline Trichuris trichiura & $13(16.5)$ & $18(28.1)$ & 0.092 & $12(17.1)$ & $19(26.0)$ & 0.197 & $12(17.6)$ & $19(25.3)$ & 0.265 \\
\hline Ascaris lumbricoides & $38(48.1)$ & $23(35.9)$ & 0.144 & $29(41.4)$ & $32(43.8)$ & 0.771 & $22(32.4)$ & $39(52.0)$ & 0.018 \\
\hline Heligmosomoides polygyrus & $2(2.5)$ & $0(0)$ & 0.2 & $2(2.9)$ & $0(0)$ & 0.146 & $1(1.5)$ & $1(1.3)$ & 0.944 \\
\hline Trichostrongylus retortaeformis & $9(11.4)$ & $8(12.5)$ & 0.839 & $8(11.4)$ & $9(12.3)$ & 0.868 & $7(10.3)$ & $10(13.3$ & 0.575 \\
\hline Enterobius vermicularis & $2(2.5)$ & $4(6.2)$ & 0.27 & $4(5.7)$ & $2(2.7)$ & 0.375 & $1(1.5)$ & $5(6.7)$ & 0.122 \\
\hline Ancylostoma sp & $1(1.3)$ & $2(3.1)$ & 0.44 & $1(1.4)$ & $2(2.7)$ & 0.584 & $1(1.5)$ & $2(2.7)$ & 0.618 \\
\hline Metastrongylus elongatus & $14(17.7)$ & $14(21.9)$ & 0.534 & $14(20.0)$ & $14(19.2)$ & 0.901 & $14(20.6)$ & $14(18.7)$ & 0.772 \\
\hline Globocephalus diducta & $5(6.3)$ & $1(1.6)$ & 0.157 & $2(2.9)$ & $4(5.5)$ & 0.434 & $2(2.9)$ & $4(5.3)$ & 0.476 \\
\hline $\begin{array}{l}\text { Oesophagostomum } \\
\text { columbianum }\end{array}$ & $8(10.1)$ & $2(3.1)$ & 0.103 & $2(2.9)$ & $8(11.0)$ & 0.058 & $4(5.9)$ & $6(8.0)$ & 0.62 \\
\hline \multicolumn{10}{|l|}{ (b) PLATHYHELMINTHES } \\
\hline Taenia saginata & $3(3.8)$ & $4(6.2)$ & 0.499 & $3(4.3)$ & $4(5.5)$ & 0.741 & $1(1.5)$ & $6(8.0)$ & 0.071 \\
\hline Hymenolepis nana & $4(5.1)$ & $4(6.2)$ & 0.759 & $2(2.9)$ & $6(8.2)$ & 0.163 & $2(2.9)$ & $6(8.0)$ & 0.189 \\
\hline Dicrocoelium hospes & $7(8.9)$ & $8(12.5)$ & 0.48 & $11(15.7)$ & $4(5.5)$ & 0.046 & $7(10.3)$ & $8(10.7$ & 0.942 \\
\hline \multicolumn{10}{|l|}{ (c) ACANTHOCEPHALANS } \\
\hline Moniliformis moniliformis & $11(13.9)$ & $6(9.4)$ & 0.403 & $6(8.6)$ & $11(15.1)$ & 0.23 & $8(11.8)$ & $9(12.0)$ & 0.965 \\
\hline \multicolumn{10}{|l|}{ (d) PROTOZOANS } \\
\hline Entamoeba histolytica & $5(6.3)$ & $9(14.1)$ & 0.122 & $6(8.6)$ & $8(11.0)$ & $8(11.0)$ & $6(8.8)$ & $8(10.7)$ & 0.711 \\
\hline Eimeria tenella & $5(6.3)$ & $7(10.9)$ & 0.323 & $8(11.4)$ & $4(5.5)$ & $4(5.5)$ & $4(5.90$ & $8(10.7)$ & 0.303 \\
\hline
\end{tabular}

inata that had non significant higher prevalence in male animals than in female animals, all other parasites gave higher prevalence in the female animals and were also non significant $(P>0.05)$ except $D$. hospes $(\mathrm{P}<0.05)$. The effect of age on the prevalence of endoparasites of bush-meat showed that all the parasites were not significant in difference between age class in animals except $A$. lumbricoides $(P<0.05)$ that was statistically higher in adult animals than in the juvenile animals.

Intensity of intestinal parasites based on season, sex and age The intensity of infection between season, sex and age among the bush-meat are presented in (Table 6). Among the eggs and oocyst recovered, A. galli had highest mean intensity in dry season and in male while $H$. nana had the highest in rainy season and in female, Globocephalus diducta had highest intensity in juvenile while the highest intensity was recorded for Trichostrongylus retortaeformis in adult. Heligomosomoides polygyrus and $A$. duodenale were the least in intensity in two seasons, for both sexes and in age class. The difference in seasons did not show statistical difference except in T. saginata and $E$. histolytica where $(p<0.05)$ and differed more in rainy season. The effect of age on the intensity did not differ between juvenile and adult animals $(P>0.05)$ and did not differ in male and in female animals except for $S$. papillosus, $A$. lumbricoides, $\mathrm{O}$. columbianum and $M$. moniliformis that showed significant difference $(P<0.05)$.

Abundance of intestinal parasites based on season, sex and age The abundance of infection between season, sex and age among the bush-meat are presented in (Table 7). Among the parasites recovered, $A$. lumbricoides had highest mean abundance in the two seasons, for both sexes and in juvenile and adult while Heligomosomoides $s p$ had the least. The difference in all parameters (season, sex and age) did not show statistical difference in variation $(P>0.05)$ except in season effect on $E$. histolytica, which differed 


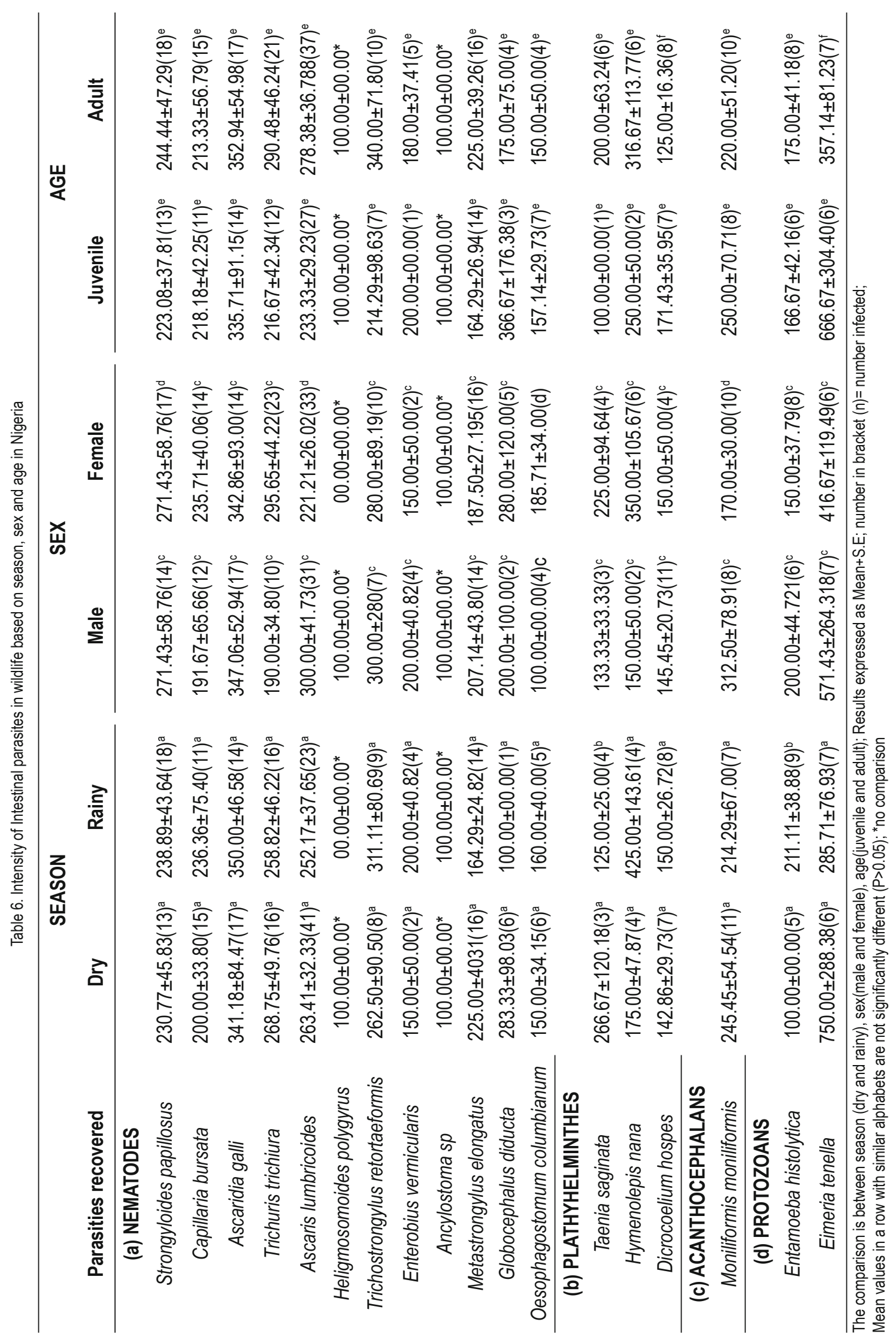


Table 7. Abundance of Intestinal parasites in wildlife based on season, sex and age in Nigeria

\begin{tabular}{|c|c|c|c|c|c|c|}
\hline \multirow[b]{2}{*}{ Parasites recovered } & \multicolumn{2}{|c|}{ SEASON } & \multicolumn{2}{|c|}{ SEX } & \multicolumn{2}{|c|}{ AGE } \\
\hline & Dry & Rainy & Male & Female & Juvenile & Adult \\
\hline \multicolumn{7}{|l|}{ (a) NEMATODES } \\
\hline Strongyloides papillosus & $43.04 \pm 13.32^{\mathrm{a}}$ & $60.94 \pm 16.9^{a}$ & $54.29 \pm 17.34^{c}$ & $47.95 \pm 12.35^{c}$ & $42.65 \pm 12.79 \mathrm{e}$ & $58.69 \pm 16.45^{\mathrm{e}}$ \\
\hline Capillaria bursata & $27.85 \pm 8.43^{a}$ & $53.13 \pm 18.63^{a}$ & $38.57 \pm 15.40^{c}$ & $39.73 \pm 11.66^{c}$ & $26.47 \pm 10.39^{e}$ & $50.67 \pm 15.58$ \\
\hline Ascaridia galli & $63.29 \pm 17.76^{a}$ & $89.06 \pm 28.44^{a}$ & $82.86 \pm 21.33^{c}$ & $67.12 \pm 23.97^{c}$ & $42.65 \pm 12.62^{\mathrm{e}}$ & $104 \pm 28.05^{e}$ \\
\hline Trichuris trichiura & $48.10 \pm 14.62^{\mathrm{a}}$ & $76.56 \pm 19.88^{a}$ & $35.71 \pm 11.51^{\circ}$ & $84.93 \pm 20.52^{\mathrm{d}}$ & $35.29 \pm 10.63^{\mathrm{e}}$ & $84.00 \pm 20.53^{f}$ \\
\hline Ascaris lumbricoides & $129.11 \pm 21.02^{\mathrm{a}}$ & $100.00 \pm 22.60^{a}$ & $132.86 \pm 26.03^{c}$ & $100.00 \pm 16.8^{c}$ & $66.18 \pm 14.90^{\mathrm{e}}$ & $161.33 \pm 25.03^{f}$ \\
\hline Heligmosomoides polygyrus & $2.53 \pm 1.77^{\star}$ & $0.00 \pm 0.00^{*}$ & $2.86 \pm 2.00^{*}$ & $0.00 \pm 0.00^{*}$ & $1.47 \pm 1.47^{\mathrm{e}}$ & $1.33 \pm 1.33^{\mathrm{e}}$ \\
\hline Trichostrongylus retortaeformis & $26.58 \pm 43.75^{\mathrm{a}}$ & $43.75 \pm 17.51^{\mathrm{a}}$ & $31.43 \pm 12.79^{c}$ & $36.99 \pm 16.26^{c}$ & $23.53 \pm 12.59 \mathrm{e}$ & $44.00 \pm 16.13^{\mathrm{e}}$ \\
\hline Enterobius vermicularis & $3.80 \pm 2.81^{\mathrm{a}}$ & $12.50 \pm 6.49^{a}$ & $11.43 \pm 5.94^{c}$ & $4.11 \pm 3.04^{c}$ & $2.94 \pm 2.94^{\mathrm{e}}$ & $12.00 \pm 5.68^{\mathrm{e}}$ \\
\hline Ancylostoma sp & $1.27 \pm 1.26^{\mathrm{a}}$ & $3.13 \pm 2.19^{a}$ & $1.43 \pm 1.42^{c}$ & $2.74 \pm 1.92^{c}$ & $1.47 \pm 1.47^{\mathrm{e}}$ & $2.67 \pm 1.87 \mathrm{e}$ \\
\hline Metastrongylus elongatus & $45.57 \pm 12.58^{a}$ & $35.94 \pm 10.76^{a}$ & $42.86 \pm 13.43^{c}$ & $39.73 \pm 10.45^{c}$ & $33.82 \pm 9.27^{e}$ & $48.00 \pm 13.73^{\mathrm{e}}$ \\
\hline Globocephalus diducta & $13.92 \pm 6.67^{\mathrm{a}}$ & $10.94 \pm 10.93^{\mathrm{a}}$ & $2.86 \pm 2.00^{\circ}$ & $21.92 \pm 11.74^{c}$ & $5.88 \pm 4.63^{\mathrm{e}}$ & $18.67 \pm 4.63^{\mathrm{e}}$ \\
\hline $\begin{array}{c}\text { Oesophagostomum } \\
\text { columbianum }\end{array}$ & $15.19 \pm 5.72^{\mathrm{a}}$ & $7.81 \pm 5.13^{\mathrm{a}}$ & $8.57 \pm 6.01^{\mathrm{c}}$ & $15.07 \pm 5.03^{c}$ & $7.35 \pm 3.81^{\mathrm{e}}$ & $16.00 \pm 6.58^{\mathrm{e}}$ \\
\hline \multicolumn{7}{|l|}{ (b) PLATHYHELMINTHES } \\
\hline Taenia saginata & $10.13 \pm 6.88^{a}$ & $7.81 \pm 4.04^{\mathrm{a}}$ & $5.71 \pm 3.45^{c}$ & $12.33 \pm 7.54^{\mathrm{c}}$ & $1.47 \pm 1.47^{\mathrm{e}}$ & $16.00 \pm 7.83^{\mathrm{e}}$ \\
\hline Hymenolepis nana & $8.86 \pm 4.83^{a}$ & $26.56 \pm 15.14^{a}$ & $4.29 \pm 3.17^{c}$ & $28.77 \pm 13.85^{c}$ & $7.35 \pm 5.26^{\mathrm{e}}$ & $25.33 \pm 13.02^{\mathrm{e}}$ \\
\hline Dicrocoelium hospes & $12.66 \pm 5.21^{\mathrm{a}}$ & $18.75 \pm 6.99^{\mathrm{a}}$ & $22.86 \pm 7.09^{c}$ & $8.22 \pm 4.67^{c}$ & $17.65 \pm 7.24^{\mathrm{e}}$ & $13.33 \pm 4.77^{\mathrm{e}}$ \\
\hline \multicolumn{7}{|l|}{ (c) ACANTHOCEPHALANS } \\
\hline Moniliformis moniliformis & $34.18 \pm 12.07^{a}$ & $23.44 \pm 10.85^{a}$ & $34.29 \pm 14.65^{c}$ & $24.66 \pm 7.99^{c}$ & $29.41 \pm 12.58^{\mathrm{e}}$ & $29.33 \pm 1086^{\mathrm{e}}$ \\
\hline \multicolumn{7}{|l|}{ (d) PROTOZOANS } \\
\hline Entamoeba histolytica & $6.33 \pm 2.75^{\mathrm{a}}$ & $29.69 \pm 10.60^{b}$ & $17.14 \pm 7.60^{c}$ & $16.44 \pm 6.76^{c}$ & $14.71 \pm 6.71 \mathrm{e}$ & $18.67 \pm 7.52^{\mathrm{e}}$ \\
\hline Eimeria tenella & $22.78 \pm 10.18^{a}$ & $73.44 \pm 37.48^{\mathrm{a}}$ & $71.43 \pm 33.38^{c}$ & $20.55 \pm 13.22^{c}$ & $13.24 \pm 6.91^{\mathrm{e}}$ & $74.67 \pm 32.99 \mathrm{e}$ \\
\hline
\end{tabular}

The comparison is between season (dry and rainy), sex(male and female), age(juvenile and adult); Results expressed as Mean+S.E;

Mean values in a row with similar alphabets are not

more in rainy season, sex effect on $T$. trichiura that differed more in female and effect of age on the abundance of $T$. trichiura and $A$. lumbricoides which differed more in adult where $\mathrm{P}<0.05$.

\section{Discussion}

This study has provided for the first time detailed quantitative data on intestinal endoparasitic fauna of commonly consumed wildlife (bush-meat) hosts, which are relatively poorly studied and documented. The results revealed that animals from the wild are heavily infected with parasites that can be transmitted to their offspring and other mammals, including humans that may be exposed to them. This poses health problems to humans. The fact that most of the animals examined have lived together in same ecological zone for a long time may explain the finding of similar parasites in different animal types. Many of these animals share many things in common and thus could easily have shared infection among themselves.

Apart from hookworm, which is well known to be transmitted through soil-contaminated hands, all the other species of intestinal parasites found are transmitted through contaminated food and water, and mostly cause diseases with symptoms of anaemia, diarrhoea and weight loss (Roberts et al., 2010). Only one trematode, $D$. hospes (10.5\%) was recovered during this study. This might be due to the fact that most of the animals sampled do not normally feed on aquatic vegetation.

This study recorded the presence of $S$. papillosus, A. lumbricodes, T. trichiura, Capillaria bursata, and $A$. galli in birds contrary to the report by Ajibade et al., (2010) which recorded no infection of birds in Obafemi Awolowo University, Ile-Ife and University of Ibadan 
Zoology gardens in Nigeria. Animals whose movement are restricted by fences are not likely to pick up accidental parasites. Wild birds are known to migrate over long distances and wide areas of land and could therefore, acquire more parasites or introduce parasites to new areas in the process (Mbaya et al., 2007).

Seasonal differences were observed in parasite intensities, which is in line with the report of Devos and Lambrechts, (2003) that most parasites tend to reach their highest biotic potentials during the rainy season. Meanwhile, $A$. lumbricoides was statistically higher in the dry season, which might be the survivors from infections acquired during the late rainy season, in line with the report by Keyyu et al., (2003), that peak contamination of the pastures in which most of these animals feed on occur just at the end of the rainy season.

Sex difference in parasitism was observed in the prevalence of $D$. hospes and also in the intensity of $S$. papillosus, A. lumbricoides and M. moniliformis which agree with the report of Poulin (1996) that sex differences in parasite prevalence or intensity are commonly observed with male of many species exhibiting higher parasitism than females. There was no definite pattern observed in the mean intensity and abundance of some of the parasites by sex, which might be attributed to different factors influencing a host at the same time. Apio et al., (2006) attributed the sex related differences to hormones that debilitate immune functions. During this survey, it was observed that hunters used raw offal and intestinal organs from this wildlife including those from wild monkeys, to feed their hunting dogs. This could be suitable avenue for transmission of zoonotic parasites to humans as in many tropical communities, dogs roam the streets untended, defecate indiscriminately and contaminate the environment with helminth eggs and larvae, protozoan cysts and other infective agents in areas where children play outdoors and adults walk the streets barefoot, picking up infections from contaminated soils (Sowemimo and Asaolu, 2008; Okoye et al.; 2011).

\section{Conclusion and Recommendations}

The result of this study suggests that bush-meats are reservoirs of various parasites of medical and veterinary importance. We recommend that animal health planners should design zoonotic awareness interventions targeted at bush-meat hunters and traders. There is the need for legislation requiring authorization for hunting including hunting-area permit, animals allowed to be hunted at particular areas (giving cultural and conservation considerations), period of hunting, etc. Also, professional health or veterinary inspection and approval of bush-meat meant for trade and consumption. The feeding of hunting dogs with raw offal and intestinal organs as observed should be discouraged and wild animal carcasses should be handled with care.

\section{References}

AJibade, W.A., Adeyemo, O.K., Agbede, S.A. (2010): Coprological survey and inventory of animals at Obafemi Awolowo University and University of Ibadan Zoological Gardens. World J. Zool., 5(4): $266-271$
Apio, A., Plath, M., Wronsk, T. (2006): Patterns of gastrointestinal parasitic infections in the bushbuck Tragelaphus scriptus from the Queen Elizabeth National Park Uganda. J. Helminthol., 80: 213 218. DOI: $10.1076 / \mathrm{JOH} 2006343$

DekeYser, P.L., Derivot, J.H. (1966): Les oiseaux de l'ouest africain. - Fascicule I. Initiations et Etudes Africaines n ${ }^{\circ} \mathrm{XIX}, 507$ pp.

Dekeyser, P.L., Derivot, J.H. (1967): Les oiseaux de l'Ouest africain. - Fascicule II. Initiations et Etudes Africaines $n^{\circ} \mathrm{XIX}, 140 \mathrm{pp}$. Devos, V., LAmBreCHTS, M.C. (2003). Emerging aspect of wildlife diseases in southern Africa. In: Proceeding of sarcus symposium on nature conservation as a farm land. Gorongosa Natural Park, Mozambique, pp. 97 - 99

Keyyu, J.D., Kassaku, A.A., Kyvsgaard, N.C., Willingham, A.L (2003): Gastrointestinal nematodes in indigenous zebu cattle under pastural and nomadic management systems in the lower plain of southern highlands of Tanzania. Vet. Res. Commun., 27: 371 - 380. DOI: 10.1023/A:1024706120270

Кoch A, Auliya M., Ziegler T. (2010): Updated checklist of living monitor lizards of the world (Squamata: Varanidae). Bonn Zool. Bull., 57: 127 - 136

LYNNE, S.G., A.B. DAVID, 2005. Diagnostic Medical Parasitology. 2nd Edn., American Society for Microbiology, Washington D.C., pp. $34-45$

Mbaya, A.W., Nwosu, C.O., Aliyu, M.M. (2007): Parasites and associated packed cell volume changes of captive wild birds in the semi-arid region of north-eastern Nigeria. Niger. J. Parasitol., 28: 109 - 113. DOI: 10.4314/njpar.v28i2.37867

Molnar R.E., PIANKA E.R. (2004): Biogeography and phylogeny of varanoids. In: PIANKa E.R., KIng D.R., King R. (Eds) Varanoid Lizards of the World. Bloomington. Indiana University Press. pp. $68-76$

Oвоүе, O. (2013): Merits and Demerits of eating game meat. Available at http://www. afrisonet.com/2013/11. Accessed 15 th Dec 2014 Okoye, I.C., Obiezue, N.R., Okorie, C.E., Ofoezie, I.E. (2011). Epidemiology of intestinal helminth parasites in stray dogs from markets in south-eastern Nigeria. J. Helminthol., 85: 415 - 420. DOI: 10.1017/S0022149X10000738

Poulin, R. (1996). Sexual inequalities in helminth infections: A cost of being a male? Am. Nat.,147:287 - 295

RoberTS, L.S., SchmidT, D.S., Janovy, J.J. (2010). Foundations of Parasitology. Eighth edition. Mc Graw Hill International, New York. Sloss, M.W., KemP, R.L., ZaJAC, A.M. (1994). Veterinary Clinical Parasitology. Fifth edition. lowa State University Press, Ames, lowa, USA

Soulsby, E.J. (1982). Helminths Arthropods and Protozoa of Domesticated Animals. Seventh Edition. Bailliere Tindall Company, London

Sowemimo, O.A., Asaolu, S.O (2008). Epidemiology of intestinal helminth parasites of dogs in Ibadan, Nigeria. J. Helminthol., 82, 89 - 93. DOI: 10.1017/S0022149X07875924

WaLkER E.P. (1999). Mammals of the World. (2 volumes). (Sixth Edition). Volume I - Baltimore and London: The Johns Hopkins University Press, $836 \mathrm{pp}$.

World Health Organisation (WHO). (2012). Managing zoonotic public health risks at the human-animal-ecosystem interface. www.who.int/zoonoses/en/. Accessed on October 22, 2013. 